\title{
EFEK PROTEKSI DEKOKTA KULIT ALPUKAT PADA HEPAR TIKUS TERINDUKSI KARBON TETRAKLORIDA
}

\section{Phebe Hendra*), Paramita Liong, Brigita Wina Rosari Putri, Angeline Syahputri Fransiskus, Fransisca Andriani, Asih Putriati, Theresia Eviani}

\author{
Fakultas Farmasi, Universitas Sanata Dharma, Yogyakarta, Indonesia
}

Received April 14, 2016; Accepted July 19, 2016

\begin{abstract}
The decoction of avocado peels was tested for their hepatoprotective activity against carbon tetrachloride-induced hepatotoxicity in rat. The rats were treated with the decoction of avocado peels at doses of 363; 762, $1600 \mathrm{mg} / \mathrm{kg}$ per oral once in a day for 6 days and carbon tetrachloride (2 $\mathrm{mL} / \mathrm{kg}$ ) was given on the 7th day. Different groups of rats were given water decoction of avocado peels at a dose of $363 ; 762,1600 \mathrm{mg} / \mathrm{kg}$ and after 6 hours received carbon tetrachloride $(2 \mathrm{~mL} / \mathrm{kg})$, respectively. The degree of protection was measured by using biochemical parameters like serum transaminase, alkaline phosphatase and albumin. From these results it suggested that the decoction of avocado peels 762, 1600 $\mathrm{mg} / \mathrm{kg}$ for 6 hours has a potent hepatoprotective action upon carbon tetrachloride-induced hepatic damage in rats.
\end{abstract}

Keywords: decoction, peel, avocado, hepatoprotective

\section{PENDAHULUAN}

Hepar sebagai organ terbesar dalam tubuh dengan berat rerata sekitar 2,5\% dari berat badan orang dewasa normal, terletak pada rongga perut bagian kanan atas. Hepar memegang peranan penting untuk mempertahankan hidup dan berperan pada hampir setiap fungsi metabolisme tubuh (Sari dkk., 2008). Salah satu jenis kerusakan hati yaitu perlemakan hati (steatosis), merupakan kondisi dimana terjadi penumpukan lemak pada hati (Fransiskus, 2011). Prevalensi perlemakan hati di Indonesia mencapai 30,6\% (Sofia dkk., 2009). Terkait dengan kejadian perlemakan hati tersebut, maka pemanfaatan tanaman dapat menjadi pengobatan alternatif.

Karbon tetraklorida $\left(\mathrm{CCl}_{4}\right)$ merupakan salah satu senyawa model hepatotoksin dengan tipe kerusakan perlemakan hepar. Senyawa ini akan menghasil radikal bebas triklorometil dengan katalis enzim sitokrom P-450 yang dapat menimbulkan peroksidasi lipid. Hasil ini dapat menyebabkan kerusakan sel berupa perlemakan hati (steatosis) (Timbrel, 2008).

Alpukat (Persea americana Mill.) selain dimanfaatkan sebagai buah, namun juga banyak digunakan sebagai obat tradisional (Marlinda, Meiske, Audy, 2012). Alpukat memiliki khasiat sebagai antioksidan yang diperoleh dari kandungan fenolnya sehingga dapat bermanfaat sebagai hepatoprotektor yang berperan dalam proteksi tubuh terhadap hepatotoksisitas (AlWasel and Bashandy, 2011). Rodriguez-Carpena et al. (2011) dan Konsinska et al. (2012) melaporkan limbah alpukat berupa biji dan kulit alpukat menunjukkan aktivitas antioksidan yang besar dibandingkan daging buah. Menurut Vinha et al. (2013) kandungan biji dan kulit alpukat hampir sama, berupa flavonoid, karotenoid, vitamin $\mathrm{C}$, dan vitamin E. Adanya kandungan flavonoid, karotenoid, dan fenolik dapat mencegah kerusakan oksidatif sel, mempunyai aktifitas perlindungan terhadap resiko kanker dan penyakit hati. Hendra dkk. (2014) melaporkan pemberian infusa dan dekokta biji alpukat selama 6 hari memberikan efek proteksi baik pada hepar maupun renal pada tikus terinduksi karbon tetraklorida. Berdasarkan hal tersebut, maka perlu diketahui apakah kulit alpukat mempunyai efek proteksi pada hepar terinduksi karbon tetraklorida. 


\section{METODE PENELITIAN}

Bahan yang digunakan dalam penelitian ini adalah kulit alpukat yang diperoleh dari depot es di Yogyakarta bulan Juni-Juli. Bahan kimia yang digunakan adalah karbon tetraklorida, aquadest, olive oil (Bertolli), kit pemeriksaan ALT, AST, ALP dan albumin. Hewan uji yang digunakan yaitu tikus jantan galur Wistar dengan berat badan antara 150-250 g, umur 2-3 bulan dan dalam keadaan sehat. Alat yang digunakan meliputi oven, mesin penyerbuk, mesin pengayak, timbangan analitik, panci infusa, shaker, spuit injeksi, serta alat-alat gelas (Pyrex).

Dekokta kulit alpukat diperoleh dengan menimbang $8,0 \mathrm{~g}$ serbuk kering kulit dan dimasukkan 16,0 $\mathrm{mL}$ aquadest ke dalam panci, kemudian ditambah aquadest sampai 100,0 mL, dipanaskan pada suhu $90^{\circ} \mathrm{C}$ selama 30 menit. Setelah 30 menit, campuran diambil dan diperas menggunakan kain flannel, lalu ditambahkan air panas secukupnya melalui ampas hingga diperoleh volume dekokta kulit alpukat (DKA) yang dikehendaki yaitu 100,0 mL.

Protokol dan prosedur penelitian yang dilakukan telah disetujui oleh Fakultas Kedokteran UGM Medical and Health Research Ethics Committee (MHREC). Sebanyak 40 ekor tikus dibagi secara acak ke dalam 8 kelompok perlakuan. Kelompok I sebagai kontrol hepatotoksin diberi larutan karbon tetraklorida $2 \mathrm{~mL} / \mathrm{kg}$ secara intraperitonial (i.p.) (Janakat dan Al Merie, 2002; Panjaitan dkk., 2007). Kelompok II sebagai kontrol negatif, olive oil sebagai pelarut karbon tetraklorida $2 \mathrm{~mL} / \mathrm{kg}$, i.p. Kelompok III-V berturut-turut diberi DKA dengan dosis berturut-turut $363 ; 762$; dan $1600 \mathrm{mg} / \mathrm{kg}$ secara oral sekali sehari selama 6 hari berturut-turut kemudian pada hari ke-7 diberi karbon tetraklorida ( $2 \mathrm{~mL} / \mathrm{kg}$, i.p.). Kelompok VIVIII diberikan DKA dengan dosis berturut-turut 363; 762; dan $1600 \mathrm{mg} / \mathrm{kg}$ secara oral sekali sehari selama 6 jam kemudian diberi karbon tetraklorida ( $2 \mathrm{~mL} / \mathrm{kg}$, i.p.). Pengambilan darah tikus dilakukan setelah 24 jam pemberian karbon tetraklorida melalui sinus orbitalis mata, lalu diukur aktivitas ALT, AST, ALP dan kadar albumin (Koyama et al., 2006; Panjaitan dkk., 2007; Arhoghro et al., 2009; Rajendran et al., 2009; Xu et al., 2010; Sivakrishnan dan Kottaimuthu, 2014). Data aktivitas ALT, AST, ALP dan kadar albumin disajikan dalam rerata \pm standar eror, selanjutnya dianalisis dengan analisis pola searah (One Way ANOVA) dengan taraf kepercayaan $95 \%$ dan dilanjutkan dengan uji Scheffe. Adanya aktivitas hepatoprotektif ditunjukkan dari kemampuan DKA untuk menurunkan aktivitas ALT, AST dan ALP serta meningkatkan kadar albumin tikus secara bermakna akibat induksi karbon tetraklorida.

Tabel 1. Pengaruh pemberian dekokta biji pada tikus terinduksi karbon tetraklorida $(n=5)$

\begin{tabular}{|c|c|c|c|c|c|}
\hline Kel. & Perlakuan & $\begin{array}{c}\text { ALT }(\mathrm{U} / \mathrm{L}) \\
(\text { rerata } \pm \mathrm{SE})\end{array}$ & $\begin{array}{c}\operatorname{AST}(\mathrm{U} / \mathrm{L}) \\
(\text { rerata } \pm \mathrm{SE})\end{array}$ & $\begin{array}{c}\text { ALP }(\mathrm{U} / \mathrm{L}) \\
(\text { rerata } \pm \mathrm{SE})\end{array}$ & $\begin{array}{l}\text { Albumin }(\mathrm{g} / \mathrm{dL}) \\
\quad(\text { rerata } \pm \mathrm{SE})\end{array}$ \\
\hline I & Kontrol olive oil ( $2 \mathrm{~mL} / \mathrm{kg})$ & $81,6 \pm 3,1^{b}$ & $127,2 \pm 7,3^{b}$ & $274,2 \pm 25,7^{\mathrm{b}}$ & $3,63 \pm 0,06^{b}$ \\
\hline II & Kontrol karbon tetraklorida $2 \mathrm{~mL} / \mathrm{kg}$ & $256,8 \pm 10,2^{\mathrm{a}}$ & $762,2 \pm 43,2^{\mathrm{a}}$ & $440,2 \pm 37,7^{\mathrm{a}}$ & $2,92 \pm 0,07^{\mathrm{a}}$ \\
\hline III & DKA $363 \mathrm{mg} / \mathrm{kg}, 6$ hari $+\mathrm{CCl}_{4}$ & $124,5 \pm 15,5^{\mathrm{a}, \mathrm{b}}$ & $185,6 \pm 56,5^{b}$ & $290,6 \pm 14,7^{b}$ & $3,28 \pm 0,09$ \\
\hline IV & DKA $762 \mathrm{mg} / \mathrm{kg}, 6$ hari $+\mathrm{CCl}_{4}$ & $348,9 \pm 27,7^{\mathrm{a}, \mathrm{b}}$ & $908,8 \pm 21,4^{\mathrm{a}, \mathrm{b}}$ & $250,4 \pm 23,6^{b}$ & $3,01 \pm 0,07^{\text {a }}$ \\
\hline $\mathrm{V}$ & DKA $1600 \mathrm{mg} / \mathrm{kg}, 6$ hari $+\mathrm{CCl}_{4}$ & $371,4 \pm 6,8^{a, b}$ & $932,2 \pm 44,1^{\mathrm{a}, \mathrm{b}}$ & $347,2 \pm 31,2$ & $2,92 \pm 0,08^{a}$ \\
\hline VI & DKA $363 \mathrm{mg} / \mathrm{kg}, 6 \mathrm{jam}+\mathrm{CCl}_{4}$ & $76,8 \pm 4,8^{b}$ & $251,5 \pm 45,4^{\mathrm{a}, \mathrm{b}}$ & $234,6 \pm 7,6^{b}$ & $3,45 \pm 0,03^{b}$ \\
\hline VII & DKA $762 \mathrm{mg} / \mathrm{kg}, 6 \mathrm{jam}+\mathrm{CCl}_{4}$ & $118,5 \pm 8,2^{\mathrm{a}, \mathrm{b}}$ & $105,2 \pm 7,6^{\mathrm{a}, \mathrm{b}}$ & $261,2 \pm 20,9^{b}$ & $3,31 \pm 0,08^{b}$ \\
\hline VIII & DKA $1600 \mathrm{mg} / \mathrm{kg}, 6 \mathrm{jam}+\mathrm{CCl}_{4}$ & $176,3 \pm 14,2^{a, b}$ & $150,8 \pm 44,9^{\mathrm{a}, \mathrm{b}}$ & $326,6 \pm 27,1$ & $3,52 \pm 0,12^{b}$ \\
\hline
\end{tabular}

Keterangan: $\mathrm{SE}=$ standard error; $\mathrm{a}=\mathrm{p}<0,05$ menunjukkan perbedaan bermakna terhadap kelompok kontrol olive oil; $\mathrm{b}=\mathrm{p}<0,05$ menunjukkan perbedaan bermakna terhadap kelompok kontrol karbon tetraklorida. 


\section{HASIL DAN PEMBAHASAN}

Aktivitas ALT, AST, APT dan kadar albumin pada ketiga dosis perlakuan dekokta kulit alpukat (DKA) 363; 762 dan $1600 \mathrm{mg} / \mathrm{kgBB}$ serta kelompok kontrol negatif olive oil dan kelompok hepatotoksin karbon tetraklorida terlihat pada Tabel 1. Hasil penelitian terjadi perubahan aktivitas serum enzim (ALT, AST, ALP) serta albumin dari serum tikus yang diinduksi dengan karbon tetraklorida. Aktivitas serum ALT, AST dan ALP memberikan kenaikan yang signifikan, sedangkan albumin memberikan penurunan signifikan bila dibandingkan dengan kontrol negatif $(\mathrm{p}<0,05)$.

Hasil metabolisme karbon tetraklorida oleh enzim sitokrom P-450 hepar berupa metabolit reaktif triklorometil. Adanya metabolit reaktif tersebut dapat merangsang terjadinya peningkatan hidroperoksida dan malondialdehid, yang lebih lanjut dapat menurunkan jumlah glutation secara signifikan di dalam jaringan hepar (Al Wasel dan Bashandy, 2011). Lebih lanjut terjadi perubahan drastis di dalam hati seperti perubahan lemak, degenerasi melemak (Nirmala, et al., 2012) serta infiltrasi sel inflamasi, yang berdampak terjadinya steatosis dan pelepasan enzim transaminase (Zimmerman, 1999; Timbrel, 2008, Gupta et al., 2004). Kenaikan aktivitas ALP sebesar 1,6-2 kali nilai normal juga terjadi akibat pemejanan karbon tetraklorida pada tikus (Weatherby and Ferguson, 2002; Mukherjee, 2002; Rajendran et al., 2009; Panjaitan et al., 2007). Sebaliknya penurunan albumin dan total protein terjadi pada tikus yang diinduksi karbon tetraklorida (Ahmed et al., 2002; Gupta et al., 2004;).

Pada hasil penelitian terlihat bahwa pemberian karbon tetraklorida pada tikus mengakibatkan peningkatan aktivitas ALT yang bermakna hingga 246,8 $\pm 10,2$ U/L (3 kali lipat dibanding nilai kontrol negatif olive oil) (Gambar 1), begitu juga dengan aktivitas AST mengalami peningkatan hingga 6 kali lipat (762,2 $\pm 43,2 \mathrm{U} / \mathrm{L})$ (Gambar 2). Peningkatan juga terjadi pada aktivitas ALP hingga mencapai 1,6 kali (Gambar 3), sebaliknya diikuti dengan penurunan albumin 1,2 kali dibandingkan normal (Gambar 4). Berdasarkan hal ini berarti dengan model induksi karbon tetraklorida telah menyebabkan terjadinya kerusakan pada hepar tikus.

Kelompok perlakuan DKA $363 \mathrm{mg} / \mathrm{kgBB}$ selama 6 hari mampu menurunkan ativitas ALT, AST dan ALP secara bermakna dan pada dosis $762 \mathrm{mg} / \mathrm{kgBB}$ selama 6 hari hanya mampu memberikan penurunan aktivitas ALP secara bermakna. Pemberian DKA $1600 \mathrm{mg} / \mathrm{kgBB}$ selama 6 hari belum mampu menurunkan aktivitas ALT, AST dan AST serta meningkatkan kadar albumin pada tikus terinduksi karbon tetraklorida. Hasil penelitian ini menunjukkan hanya pemberian dekokta kulit alpukat dosis $363 \mathrm{mg} / \mathrm{kgBB}$ selama 6 hari yang mempunyai aktivitas penurunan aktivitas ALT, AST dan ALP, namun belum mampu meningkatkan kadar albumin tikus akibat induksi karbon tetraklorida.

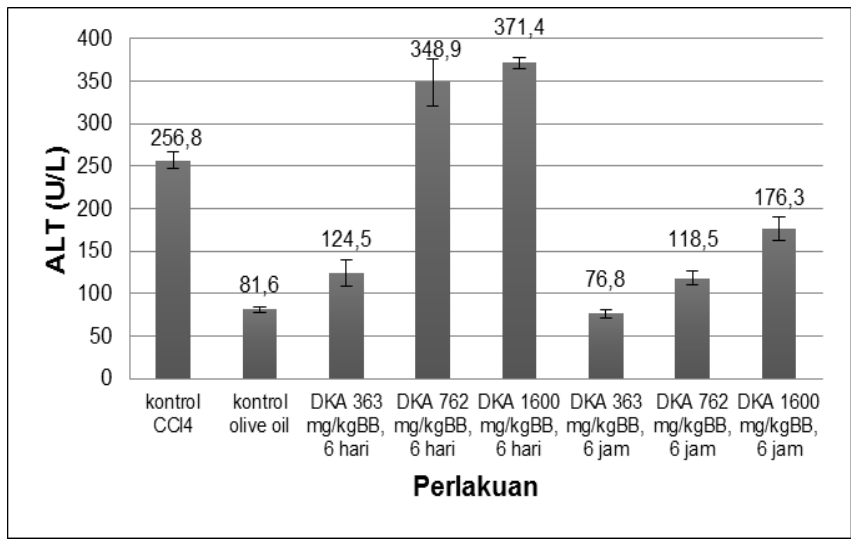

Gambar 1. Pengaruh pemberian dekokta kulit alpukat (DKA) terhadap ALT tikus terinduksi karbon tetraklorida $(\mathrm{n}=5)$.

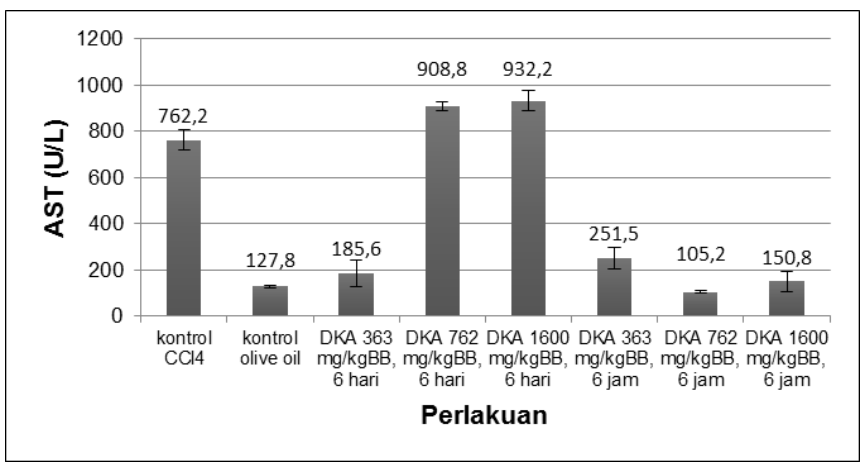

Gambar 2. Pengaruh pemberian dekokta kulit alpukat (DKA) terhadap AST tikus terinduksi karbon tetraklorida $(n=5)$. 


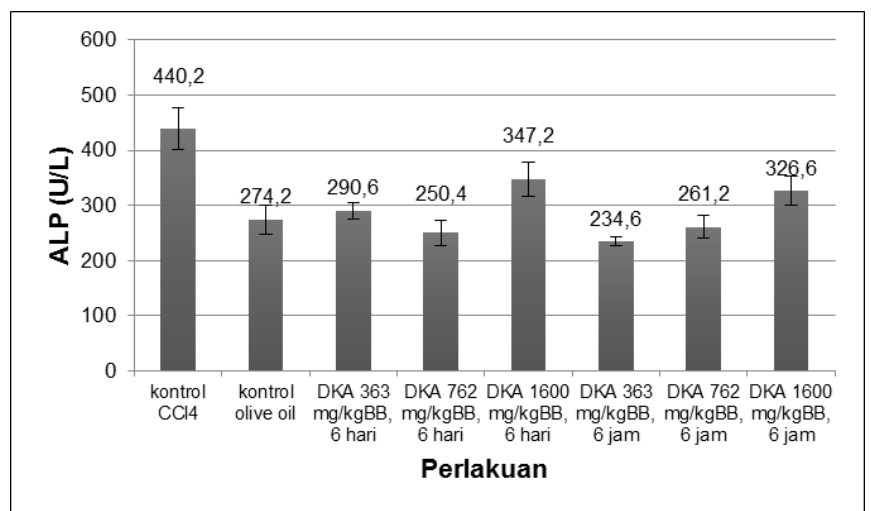

Gambar 3. Pengaruh pemberian dekokta kulit alpukat (DKA) terhadap ALP tikus terinduksi karbon tetraklorida $(n=5)$.

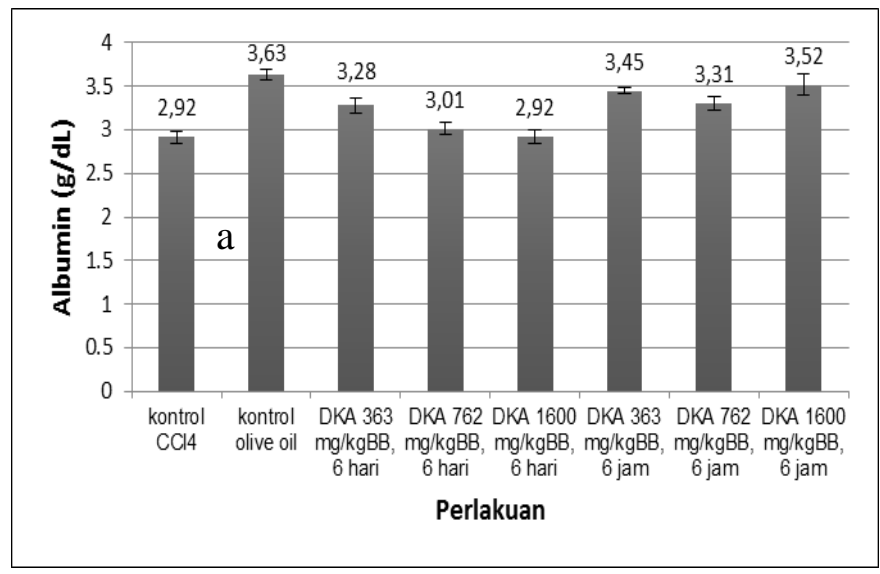

Gambar 4. Pengaruh pemberian dekokta kulit alpukat (DKA) terhadap albumin tikus terinduksi karbon tetraklorida $(\mathrm{n}=5)$.

Kelompok perlakuan DKA 363 dan 762 $\mathrm{mg} / \mathrm{kgBB}$ selama 6 jam mampu menurunkan ativitas ALT, AST dan ALP serta menaikkan albumin secara bermakna, sedangkan dosis 1600 $\mathrm{mg} / \mathrm{kgBB}$ selama 6 jam hanya mampu memberikan penurunan aktivitas ALT, AST serta menaikkan albumin secara bermakna pada tikus terinduksi karbon tetraklorida. Hal ini menunjukkan adanya aktivitas hepatoprotektif berupa penurunan aktivitas ALT, AST dan ALP serta peningkatan kadar albumin pada pemberian DKA 363 dan 762 $\mathrm{mg} / \mathrm{kgBB}$ selama 6 jam. Adanya aktivitas penurunan ALP serta peningkatan albumin dari DKA 363 dan $762 \mathrm{mg} / \mathrm{kgBB}$ selama 6 jam menunjukkan telah terjadi mekanisme perbaikan sekretori dari sel hepatik akibat toksisitas karbon tetraklorida. Ini berarti pemberian dekokta kulit alpukat 363 dan $762 \mathrm{mg} / \mathrm{kgBB}$ selama 6 jam mampu memberikan proteksi hepar terhadap ketoksikan karbon tetraklorida.

Kemampuan kulit alpukat memberikan aktivitas proteksi hepar terhadap ketoksikan karbon tetraklorida dimungkinkan oleh adanya aktivitas antioksidan yang terkandung berupa senyawa golongan flavonol di dalam kulit alpukat (Rodriguez-Carpena et al., 2011 dan Konsinska et al., 2012). Adanya kandungan tersebut dapat mencegah kerusakan oksidatif sel, mempunyai aktifitas perlindungan terhadap resiko ketoksikan karbon tetraklorida. Namun pemberian DKA 762 dan $1600 \mathrm{mg} / \mathrm{kgBB}$ selama 6 hari terjadi peningkatan ALT dan AST yang siginifikan dibandingkan kontrol karbon tetraklorida, hal ini mungkin disebabkan oleh kadar antioksidan di dalam DKA dalam jumlah yang besar dan dipejankan ke tikus dalam jangka waktu yang lama. Krizkova et al. (2009) melaporkan pemberian antioksidan, flavonoid dalam jumlah berlebihan dapat memberikan dampak yang tidak diinginkan pada hepar tikus, terutama pada aktivitas sitokrom P450.

Adapun pemberian DKA pada ketiga peringkat dosis selama 6 hari tidak menunjukkan aktivitas yang serupa seperti DKA dengan pemberian 6 jam. Hal ini mungkin berkaitan dengan mekanisme proteksi yang berbeda yang disebabkan oleh waktu pemberian. Oleh karena itu perlu dilakukan penelitian lanjutan terkait dengan mekanisme proteksi yang disebabkan oleh lama pemberian sediaan.

\section{KESIMPULAN}

Pemberian dekokta kulit alpukat dosis 363 dan $762 \mathrm{mg} / \mathrm{kgBB}$ selama 6 jam mempunyai efek hepatoprotektif pada tikus terinduksi karbon tetraklorida.

\section{DAFTAR PUSTAKA}

Ahmed, B., Alam, T., Varshney, M., Khan, S.A., 2002. Hepatoprotective activity of two plants 
belonging to the Apiaceae and the Euphorbiaceae family. Journal of Ethnopharmacology, 79, 313-316.

AlWasel, A.H., and Bashandy, S.A., 2011. Carbon Tetrachloride-induced Hepatotoxicty and Nephrotoxicity in Rats: Protective Role Vitamin C. Journal of Pharmacology and Toxicology, 6 (3), 283-292.

Arhoghro, E.M., Ekpo, K.E., and Ibeh, G.O., 2009. Effect of Aqueous Extract of Scent Leaf (Ocimum gratissimum) on Carbon Tetrachloride $\left(\mathrm{CCl}_{4}\right)$ Induced Liver Damage in Albino Wistar Rats. African Journal of Pharmacy and Pharmacology, 3 (11), 562567.

Fransiskus, A., 2011. Disease Progression: Steatosis, Hepatitis C Support Project, version3,

http://www.hcvadvocate.org/hepatitis/factshee ts_pdf/ steatosis.pdf, diakses 15 Februari 2013.

Gupta, M., Mazumder, U.K., Kumar, T.S., Gomathi, P., Kumar, R.S., 2004. Antioxidant and hepatoprotective effects of Bauhinia racemosa against paracetamol and carbon tetrachloride induced liver damage in rats. Iranian Journal of Pharmacology \& Therapeutic, 3 (1), 12-20.

Hendra, P., Krisnadi, G., Perwita, N.L.P.D., Kumalasari, I., Quraisyin, Y.A., 2014. Hepatoprotective and nephroprotective effects of avocado seeds against carbon tetrachloride in rats. Trad. Med. J., 19 (3), 133-137.

Janakat, S., Al-Merie, H., 2002. Optimization of the dose and route of injection, and characterisation of the time course of carbon tetrachloride-induced hepatotoxicity in the rat. Journal of Pharmacological and Toxicological Methods, 48, 41-44.

Kosinska, A., Karamac, M., Estrella, I., Hernandez, T., Bartolome, B., Dykes, G.A., 2012. Phenolic compound profiles and antioxidant capacity of Persea americana Mill. peels and seeds of two varieties. Journal of Agricultural and Food Chemistry, 60, 4613-4619.
Koyama, T., Chounan R., Uemura, D., Yamaguchi K., Yazawa K., 2006. Hepatoprotective effect of a hot-water extract from the edible thorny oyster Spondylus varius on carbon tetrachloride induced liver injury in mice. Biosci. Biotechnol. Biochem., 70 (3), 729731.

Krizkova, J., Burdova, K., Stiborova, M., Kren, V., Hodek, P., 2009. The Effect of Selected Flavonoids on Cytocrhromes P450 in Rat Liver and Small Intestine. Interdisc. Toxicol., 2 (3), 201-204.

Marlinda, M., Meiske, S.S., Audy, D.W., 2012. Analisis Senyawa Metabolit Sekunder dan Uji Toksisitas Ekstrak Etanol Biji Buah Alpukat (Persea americana Mill.). Jurnal MIPA UNSRAT, 1 (1), 24-28.

Mukherjee, P.K., 2002. Quality control of herbal drugs, 1st ed.

Nirmala, M., Girija, K., Lakshman, K., Divya, T., 2012. Hepatoprotective activity of Musa paradisiacal on experimental animal models. Asian Pasific Journal of Tropical Biomedicine, 11-15

Panjaitan RGP, Handharyani E, Chairul, Masriani, Zakiah Z, Manalu W., 2007. Pengaruh Pemberian Karbon Tetraklorida terhadap Fungsi Hati dan Ginjal Tikus. Makara Kesehatan, 11 (1), 11-16.

Rajendran, R., Hemalatha, S., Akaskalai, K., MadhuKrishna, C. H., Sohil, B., Vittal, Sundaram, R.M., 2009. Hepatoprotective Activity of Mimosa pudica leaves against Carbontetrachloride induced toxicity. Journal of Natural Products, 2, 116-122.

Rodriguez-Carpena, J.G., Morcuende, D., Andrade, M.J., Kylli, P., Estevez, M., 2011. Avocado (Persea americana Mill.) phenolics, in vitro antioxidant and antimicrobial activities, and inhibition of lipid and protein oxidation in porcine patties. Journal of Agricultural and Food Chemistry, 59, 5625-5635.

Sari, W., Indrawati, L., Djing, O.I., 2008. Care Your Self Hepatitis. 
Sivakrishnan, S. and Kottaimuthu, A., 2014. Hepatoprotective activity of ethanolic extract of aerial parts of Albizia procera Roxb (Benth.) against paracetamol induced liver toxicity on Wistar rats. International Journal of Pharmacy and Pharmaceutical Science, 6 (1), 233-238.

Sofia, N.A., Nurdjanah, S., Ratnasari, N., 2009. Kadar Leptin Pada Populasi non Diabetes dengan dan tanpa Non-Alcoholic Fatty Hati. Berkala Kesehatan Klinik, 15 (1), 49-55.

Timbrel, J. A., 2008. Principles of Biochemical Toxicology, 4th Edition.

Vinha, A.F., Moreira, J., and Barreira, S.V.P., 2013. Physicochemical Parameters, Phytochemical
Composition and Antioxidant Activity of the Algarvian Avocado (Persea americana Mill.). Journal of Agricultural Science, 5 (12), 100-109.

Weatherby, D., and Ferguson, S., 2002. Blood Chemistry and CBC Analysis : Clinical Laboratory Testing from a Functional Perspective.

Xu, G.H., Chen, D.H., Xhang, Y.H., Jiang, P., Ye, X.Q., 2008. Minerals, Phenolic Compounds, and Antioxidant Capacity of Citrus Peel Extract by Hot Water. Journal of Food Science. 73 (1), 11-18.

Zimmerman, H.J., 1999. Hepatotoxicity, $2^{\text {nd }}$ edition. 